ニクス複合体の界面に注目したプロトンダイナミックスを, 水素スピンー格子緩和時間の解析結果などに基づき詳しく解 説した。種々の硫酸水素塩と WPA の複合体のキャラクタリ ゼーション結果から，イオン交換反応と水素結合ネットワー クの変化が高いプロトン伝導性の実現に本質的に重要である ことを明らかにした。さらに, PBI-WSiA-CsHSO ${ }_{4}$ 系コンポ ジット膜が中温無加湿作動燃料電池の電解質として非常に有 望であることを紹介した，無機固体酸ナノプロトニクス複合 体の合成と中温燃料電池への応用に関する研究は, 学術的に も，実用的にも非常に楽しみな分野であり，今回，皆さんに 関心をもって頂ける情報を提供できたのであれば幸いである。

\section{謝 辞}

本研究は, 兵庫県立大学工学研究科大幸裕介助教抄よび産 業技術総合研究所計測フロンティア研究部門ナノ移動解析研 究グループ林繁信主任研究員との共同研究によるものである. 本研究を遂行するにあたり, 貴重な議論を頂いている物質・ 材料機構ナノ材料科学環境拠点燃料電池グループ森利之リー ダー, 豊橋技術科学大学逆井基次名誉教授, 武藤浩行准教授, 河村剛助教に感謝する. 本研究の一部は, 科学研究費補助金 「特定領域研究」439ナノイオニクス (No.19017009), 挑戦 的萌芽研究 (No.21655075), 村田学術振興財団などの支援に よって行われたものである。

\section{文 献}

1) Solid State Ionics for Batteries (Ed., T. Minami), SpringerVerlag, Tokyo, p.73 (2005).

2) Fast Proton-Ion Transport Compounds (Eds., U. B. Mioc and M. Davidovic), Transworld Research Network, Kerala, India, p.1 (2010).

3）ナノイオニクスー最新技術とその展望, 山口 周, p.181. シーエムシー出版 (2008).

4) A. Matsuda, V. H. Nguyen, Y. Daiko, H. Muto, and M. Sakai, Solid State Ionics, 181, 180 (2010).

5) Y. Daiko, V. H. Nguyen, T. Yazawa, H. Muto, M. Sakai, and A. Matsuda, Solid State Ionics, 181, 183 (2010).

6) Y. Daiko, S. Hayashi, and A. Matsuda, Chem. Mater, 22, 3418 (2010).
7）グエンハイヴァン, 大幸裕介, 武藤浩行, 逆井基次, 松 田厚範, 第 35 回固体イオニクス討論会講演要旨集, p.174 (2009).

8) S-Y. Oh, T. Yoshida, G. Kawamura, H. Muto, M. Sakai, and A. Matsuda, J. Power Sources, 195, 5822 (2010).

9) S-Y. Oh, T. Yoshida, G. Kawamura, H. Muto, M. Sakai, and A. Matsuda, J. Mater. Chem., 20, 6359 (2010).

10）吉田敏宏, 吳松 烈, 河村 剛, 武藤浩行, 松田厚範, 2010 年電気化学秋季大会講演要旨集, $1 \mathrm{E} 04$, p.73 (2010).

11) A. I. Baranov, L. A. Shuvalov, and N. M. Shchagina, JETP Lett., 36, 459 (1982).

12) B. Baranowski, M. Friesel, and A. Lundén, Physica A: Statistical Mechanics and its Applications, 156, 353 (1989).

13) S. M. Haile, D. A. Boysen, C. R. I. Chisholm, and R. B. Merle, Nature, 410, 910 (2001).

14) V. G. Ponomareva, N. F. Uvarov, G. V. Lavrova, and E. F. Hairetdinov, Solid State Ionics, 90, 161 (1996).

15) J. F. Keggin, Nature, 131, 908 (1933).

16) O. Nakamura, T. Kodama, I. Ogino, and Y. Miyake, Chem. Lett., 8, 17 (1979).

17) T. Okuhara, N. Mizuno, and M. Misono, Adv. Catal., 41, 113 (1996).

18) A. Matsuda, T. Kikuchi, K. Katagiri, H. Muto, and M. Sakai, Solid State Ionics, 177, 2421 (2006).

19) S. Furusawa, S. Miyaoka, and Y. Ishibashi, J. Phys. Soc. Jpn., 60 (1991) 1666.

20) S-Y. Oh, E. K. Insani, V. H. Nguyen, G. Kawamura, H. Muto, M. Sakai, and A. Matsuda, Science and Technology of Advanced Materials (2011) in press.

21）河合啓介, 点松烈, 大幸裕介, 武藤浩行, 逆井基次, 松 田厚範, 第 36 回固体イオニクス討論会講演要旨集, p.170 (2010).

○著者プロフィール

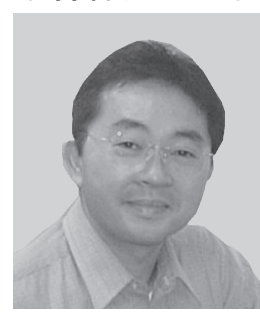

氏名：松田 厚範 Atsunori MATSUDA 所属：豊橋技術科学大学大学院工学研究科 役職：教授 趣味：剣道

\title{
錯体水素化物を用いた 新規リチウムイオン伝導体群
}

前川 英己

\section{1 はじめに}

リチウム二次電池の安全性の飛躍的向上のため全固体化が 有効であるとされる，全固体電池実現には固体電解質材料が 必須であるが, 従来知られた酸化物系, 硫化物系などのリチ ウムイオン伝導材料は何れも一長一短があり，技術開発は途 上であるといえる。本稿では, リチウムイオン電解質として
最近新しく見出された水素化物系イオン伝導体を紹介する. 従来, 窒化物, アミド, イミド系材料でリチウムイオン伝導 を示す材料は 1970 年代から知られていた。最初にそれらの 紹介を行った後, 我々のグループで開発した全く新規な高リ チウムイオン伝導を示す一連の水素化物材料について, リチ ウムボロハイドライド $\left(\mathrm{LiBH}_{4}\right)$ を中心とする最新の研究状 
況を紹介し，その材料開発，応用展開について言及する.

\section{2 既知の水素含有リチウムイオン伝導体}

2.1 水素化 $a-\mathrm{Li}_{3} \mathrm{~N}$

非常によく知られた高リチウムイオン伝導体， $\alpha-\mathrm{Li}_{3} \mathrm{~N}$ は， 1957 年 Masdupuyにより発見された ${ }^{1)}$ 。単結晶で非常に高 い伝導度が発現し ${ }^{2)}$ ，また，水素ドープによる伝導度向上が 示された ${ }^{3)}$. Fig. 1 に示すように，結晶は $\mathrm{Li}_{2} \mathrm{~N}$ 二次元平面 と層間 $\mathrm{Li}$ から構成され， $\left[\mathrm{Li}_{2} \mathrm{~N}\right]$ の稜共有による 2 次元面の Li（2）イオンが浅いポテンシャルをホッピングする伝導機 構が示唆される ${ }^{4)}$. 2 次元的なイオン伝導であり，伝導度は $c$ 軸に垂直方向と水平方向で活性化エネルギーに大きな差異 を有する (Fig. 2)。その後, $\alpha-\mathrm{Li}_{3} \mathrm{~N}$ へ水素をドープするこ とにより伝導度が向上することが，Lapp とSkaarupにより 示された ${ }^{3)}$. Fig. 2 に示すように, $0.5 \sim 1.0 \mathrm{~mol} \%$ の水素の 添加により, 単結晶試料の伝導度が 1 桁上昇することが報告 されている。一方で, $\mathrm{Li}_{3} \mathrm{~N} へ$ の異種金属イオン $(\mathrm{Mg}, \mathrm{Cu}$, $\mathrm{Al}$ ）添加は伝導度を低下させることが知られる ${ }^{3)}$. 水素化に よる伝導度向上は, 化学結合への寄与と, フレンケル欠陥生 成と移動度の増加による内因性効果と考えられる ${ }^{3)}$. 単結晶 での非常に高いイオン伝導性の一方で, 多結晶試料の伝導度 は大きく減少し，大きな粒界抵抗と伝導の異方性に起因する とされる. $\mathrm{Li}_{3} \mathrm{~N}$ は高い伝導度を示す大変興味深い材料であ るが，欠点はその熱力学的に計算される電位空がわずか $0.44 \mathrm{~V}$ しかないことであり, 固体電池など電気化学素子への 応用に制約を受ける.

2.2 リチウムイミド $\left(\mathrm{Li}_{2} \mathrm{NH}\right)$

リチウムイミド（ $\mathrm{Li}_{2} \mathrm{NH} ）$ は, Huggins らにより伝導度が

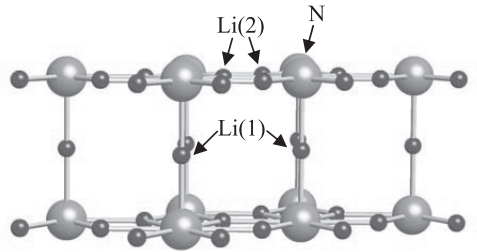

(a)

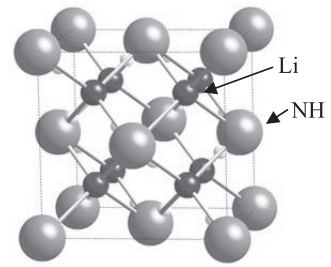

(b)
Fig. 1 (a) $\mathrm{Li}_{3} \mathrm{~N}^{2}$ および (b) $\mathrm{Li}_{2} \mathrm{NH}^{6)}$ の結晶構造.

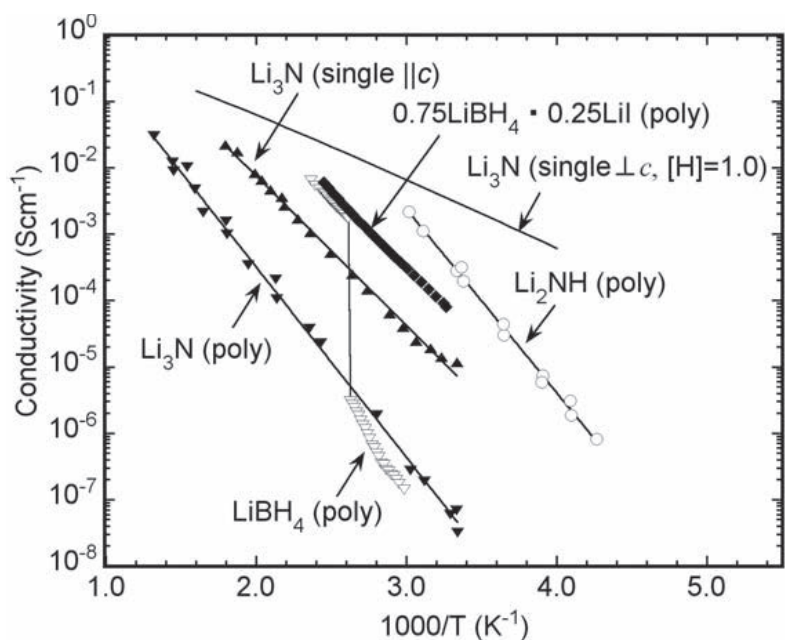

Fig. 2 様々な窒化物, 水素化物のリチウムイオン伝導の温度依存性. （poly）は多結晶体，(single）は単結晶での測定值を示す 23,5,9, 10).
報告された ${ }^{5)}$. 合成には $\mathrm{Li}_{3} \mathrm{~N}$ から $\mathrm{Li}_{2} \mathrm{NH}$ と $\mathrm{LiH}$ の混合物を 得, その後熱分解により, 残留 $\mathrm{LiH}$ を $\mathrm{Li}_{2} \mathrm{NH}$ へと変換して 得られる。

Fig. 1 に示すように $\mathrm{Li}_{2} \mathrm{NH}$ は, $\mathrm{Li}_{2} \mathrm{O}$ と同様な逆蛍石型を 基本とし， $\mathrm{NH}^{2-}$ 陰イオンによる面心立方格子の四面体位置 にリチウムイオンが配置している ${ }^{5,6)} . \mathrm{Li}_{2} \mathrm{O}(0.4611 \mathrm{~nm})$ と 比較し， $\mathrm{NH}^{2-}$ の陰イオンサイズが大きいため格子定数は 10 \%ほど伸びる $(0.5047 \mathrm{~nm}) . \mathrm{Li}_{3} \mathrm{~N}$ と比較してリチウムイオ ン伝導の活性化エネルギーは $0.55 \mathrm{eV}$ と高いが，伝導度の絶 対值が大きく, 多結晶体では $\mathrm{Li}_{3} \mathrm{~N}$ の 3 枌以上高い伝導度を示 すことと，伝導方向が等方的であることが有利な点である ${ }^{5}$. 粗い見積もりでは, $\mathrm{LiNH}_{2}$ の電位㝕は約 $0.7 \mathrm{~V}$ と計算されて おり, $\mathrm{Li}_{3} \mathrm{~N}$ の $0.44 \mathrm{~V}$ と比較して若干広い.

\section{3 リチウムボロハイドライド $\left(\mathrm{LiBH}_{4}\right)$}

リチウムボロハイドライド $\left(\mathrm{LiBH}_{4}\right)$ は, 最も水素含有量 の多い固体材料の一つであり, 近年, 水素吸蔵材料として期 待が高まっている。 しかし, 金属系材料と異なり共有結合性 の強い化合物で吸放出を実現するのは，挑戦的課題であると も考元られる. 吸放出を比較的低い圧力下でしかも可逆的に 行うためには，適切な触媒による活性化エンタルピー低下の 実現が大きな鍵である ${ }^{7)}$. 水素放出の可逆性を向上させるた め, 中森, 松尾らは水素化物錯体への高周波加熱による分解 を試みたところ， $\mathrm{LiBH}_{4}$ の異常な過熱現象を観測した ${ }^{8)}$ 。 そ の誘電損失スペクトルは低周波成分まで広がり，高イオン伝 導の可能性が考えられた

\section{1 リチウムボロハイドライドのリチウムイオン伝導特性}

Fig. 3 に， $\mathrm{LiBH}_{4}$ の Nyquist 図の温度依存性を示す。驚く べきことに, $\mathrm{Li}$ 金属を両電極に用いた交流インピーダンス スペクトルでは，低周波側の電極分極が全く観測されなかっ た。直流抵抗は，交流インピーダンス測定と一致し， $\mathrm{Li}^{+}$イ オン輸率が 1 であることがわかったＦig. 4 に示す広幅 ${ }^{7} \mathrm{Li}$ $\mathrm{NMR}$ スペクトルでは, $\mathrm{LiBH}_{4}$ 結晶の構造相転移温度 $\left(115^{\circ} \mathrm{C}\right)$ において，大幅な線幅の減少がみられる ${ }^{9,10)}$ 。また，スピン 一格子緩和時間 $\left(T_{1}\right)$ は, $200^{\circ} \mathrm{C}$ 付近に最小值を持ち，その 解析により, $\mathrm{LiBH}_{4}$ はイオン輸率 1 のリチウムイオン伝導体 であることが分かった.

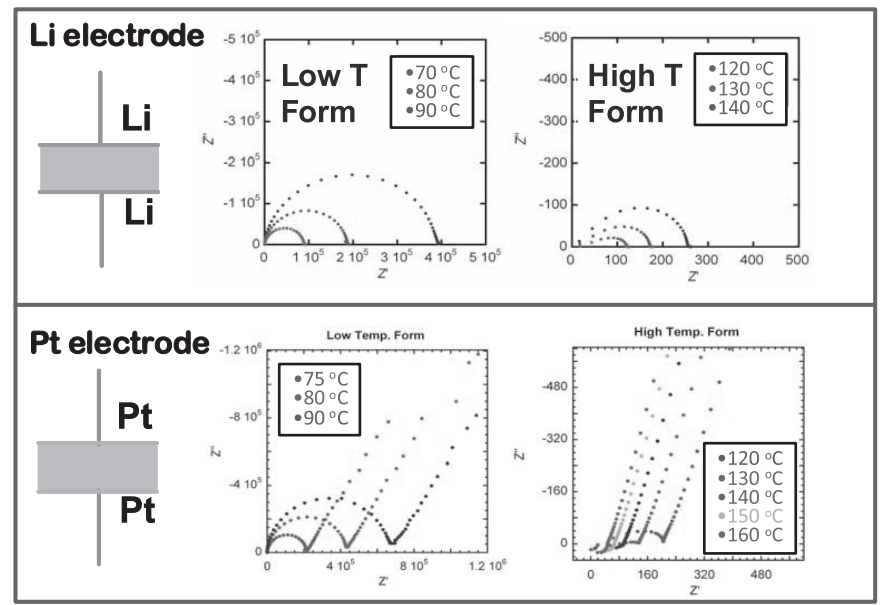

Fig. $3 \mathrm{LiBH}_{4}$ の低温相 $\left(70^{\circ} \mathrm{C}, 80^{\circ} \mathrm{C}, 90^{\circ} \mathrm{C}\right)$ および高温相 $(120$ $\left.{ }^{\circ} \mathrm{C}, 130^{\circ} \mathrm{C}, 140{ }^{\circ} \mathrm{C}\right)$ の交流インピーダンス測定によって得られた Nyquist 図. 

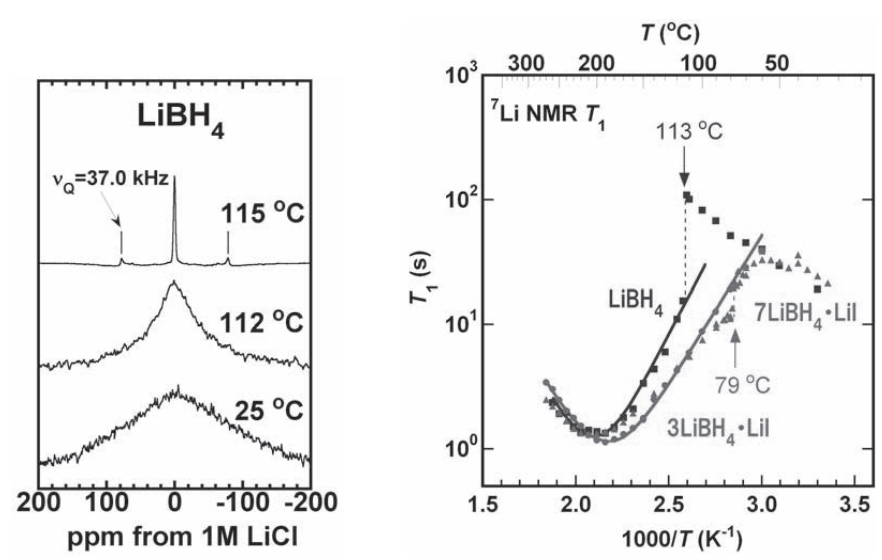

Fig. 4 (左) $\mathrm{LiBH}_{4}$ の広幅 ${ }^{7} \mathrm{Li} \mathrm{NMR}$ 測定結果 ${ }^{9}$. (右) $\mathrm{LiBH}_{4}$ 及 び LiI ドープ $\mathrm{LiBH}_{4}$ の ${ }^{7} \mathrm{Li}$ NMR $T_{1}$ 測定結果 ${ }^{10)}$.
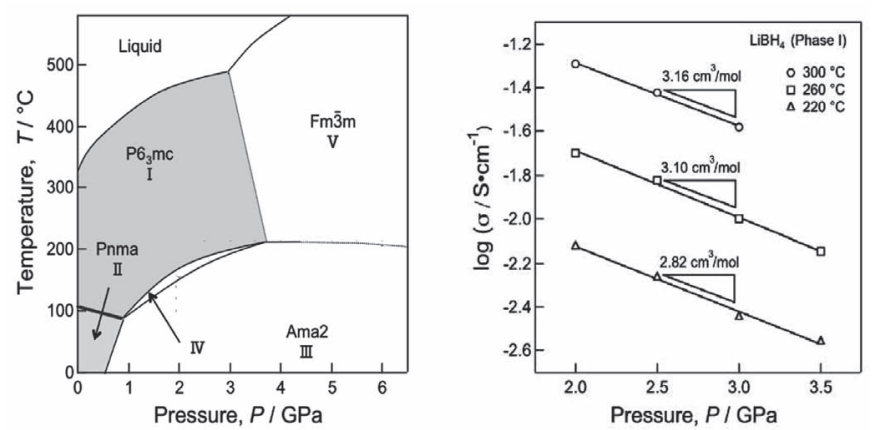

Fig. 5 (左) $\mathrm{LiBH}_{4}$ の $P-T$ 相図. 高イオン伝導相 $\left(\mathrm{P} 6{ }_{3} m c(\mathrm{I})\right)$ の 安定領域が、圧力と共に低温側に移動する特異な挙動を示す ${ }^{12)}$. （右） $\mathrm{LiBH}_{4}$ のリチウムイオン伝導度の圧力依存性. 傾きが活性 化体積を与える ${ }^{13)}$.

$\mathrm{LiBH}_{4}$ の高イオン伝導性由来を結晶構造に求めると, 極め て興味深い点が明らかになった. $\mathrm{LiBH}_{4}$ の相図は, Fig. 5 に 示すように，非常に特徵的な $P-T$ 関係を持つ ${ }^{12)}$. 高温相の 安定領域が高圧力下で低温に向かって広がり, 通常結晶での 高温相から低温相への密度の減少と正反対である。このよう な振る舞いは, $\alpha-A g I$ の超イオン伝導相でも観測され, 結晶 構造内の構造欠陥の安定性が高いことを示す. $\mathrm{LiBH}_{4}$ の電気 伝導度の活性化体積が高村らによって決定された ${ }^{13)}$. Fig. 5 に示すように，活性化体積は圧力に対する伝導度の変化とし て決定される. $\mathrm{LiBH}_{4}$ の活性化体積は, $260{ }^{\circ} \mathrm{C}$ で $3.1 \mathrm{~cm}^{3} / \mathrm{mol}$ と代表的なイオン伝導体である $\alpha-\mathrm{AgI}\left(0.8 \mathrm{~cm}^{3} / \mathrm{mol}\right)$ や NASICON* $\left(1.5 \mathrm{~cm}^{3} / \mathrm{mol}\right)$ に近く, $\mathrm{NaCl}\left(38.5 \mathrm{~cm}^{3} / \mathrm{mol}\right)$ などの完全結晶に比べはるかに小さい。このことは, $\mathrm{LiBH}_{4}$ の結晶構造 ${ }^{14)}$ (Fig. 6), 特に高温相の結晶構造において構造 由来の欠陥の存在を示し, それがこの系での高イオン伝導の 本質であることを示唆している.

\section{2 リチウムボロハイドライドのリチウムイオン伝導相 の室温安定化}

実電池への応用に当たり, $\mathrm{LiBH}_{4}$ の比較的高い相転移温度 $\left(113^{\circ} \mathrm{C}\right)$ が室温付近での応用にあたっての障害になっている. 前川らは, $\mathrm{LiBH}_{4}$ に LiCl, LiBr, LiI などのハロゲン化物が 固溶可能であること, また, 特に LiI の固溶によって超イオ ン伝導相が室温まで安定化可能であることを示した ${ }^{10,15,16)}$.

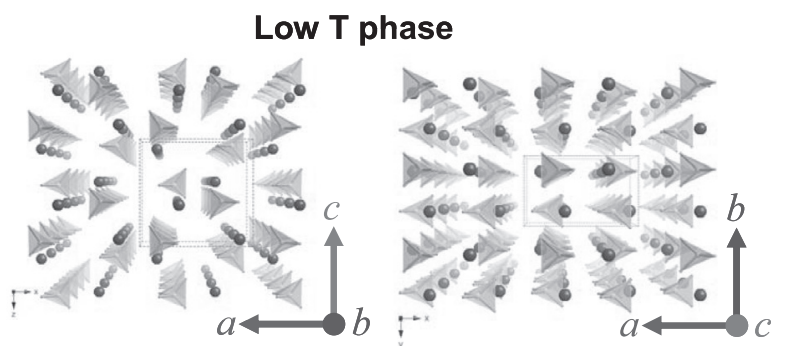

High T phase

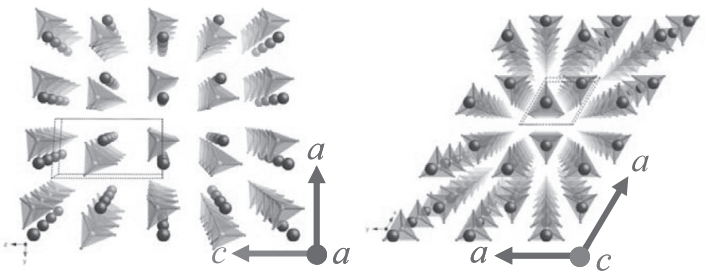

Fig. $6 \mathrm{LiBH}_{4}$ の結晶構造. 低温相と高温相 ${ }^{14)}$.

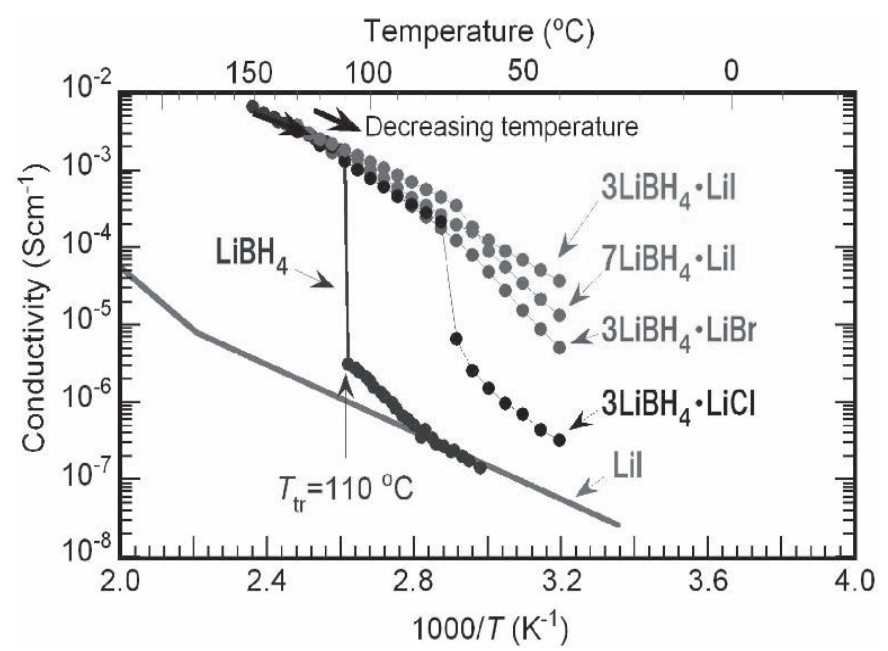

Fig. $7 \mathrm{LiX}(\mathrm{X}=\mathrm{Cl}, \mathrm{Br}, \mathrm{I})$ ドープ $\mathrm{LiBH}_{4}$ におけるリチウムイ オン伝導度の温度依存性. 降温時の測定結果 ${ }^{10)}$.

Fig. 7 に, LiCl, LiBr, LiI を固溶した $\mathrm{LiBH}_{4}$ のイオン伝導 度を示す. $115^{\circ} \mathrm{C}$ 付近に観測される構造相転移に伴うイオン 伝導度の 3 桁以上もの減少が $\mathrm{LiX}$ ドープ試料では抑えられ, 特に $3 \mathrm{LiBH}_{4} \cdot \mathrm{LiI}$ 試料では室温付近までその伝導度低下が抑 えられている。 これは, LiI の固溶により構造相転移が低温 まで抑えられていることを示している，宮崎らは，結晶格子 の変化を詳細に観測し, LiI 固溶による格子定数の増加で, $a$ 軸の膨張率が, $c$ 軸より大きく, 4 個の $\mathrm{Li}^{+}$陽イオンによっ て形成される歪んだ四面体内部に存在する $\mathrm{BH}_{4}{ }^{-}$陰イオンの $\mathrm{I}^{-}$イオンへの置換が, その局所的な対称性を変化させている と考え，構造安定性を説明した ${ }^{17)}$ 。宮崎らは伝導度の活性 化エネルギーの LiI 添加量依存性を調べ，Fig. 8 に示すよう に LiI $12 \%$ 付近に最小值を示すことを明らかにした。このこ とは, $\mathrm{BH}_{4}^{-}$の $\mathrm{I}^{-}$置換に伴うイオン伝導経路の変化によりボ トルネックの活性化エネルギーが低下すると考えると説明可 能である。

一方, ${ }^{1} \mathrm{H}$ NMR 測定によって, この超イオン伝導相におけ る $\mathrm{BH}_{4}{ }^{-}$陰イオンは, 室温付近でおよそ $10 \mathrm{GHz} も の$ 高速で 


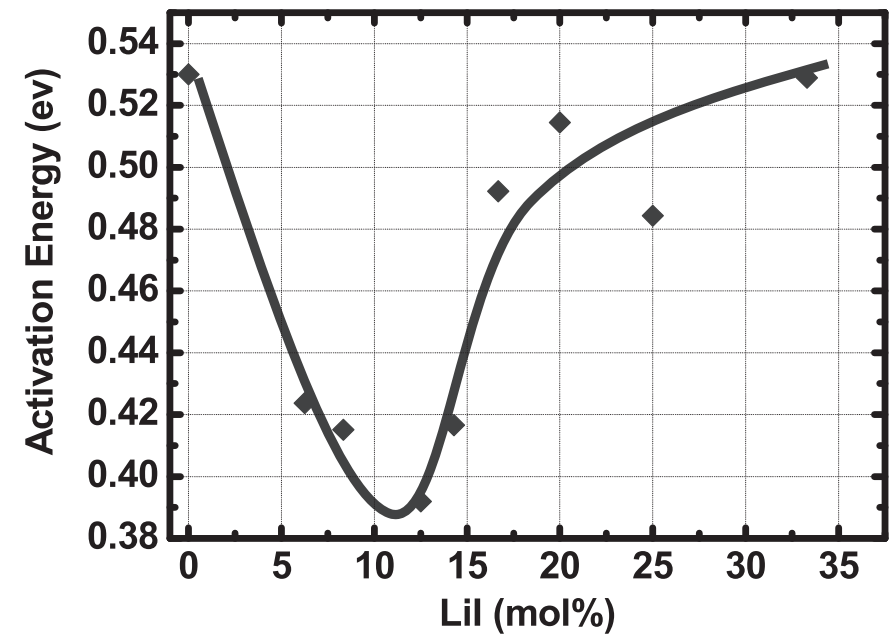

Fig. $8 \mathrm{LiI}$ ドープ $\mathrm{LiBH}_{4}$ におけるリチウムイオン伝導活性化エ ネルギーの LiI 濃度依存性 ${ }^{17)}$.

分子内回転運動している事が確認された，高温相では，さら にその 2 桁回転速度の上昇があることが測定により明らかに なった。これは， $\mathrm{Li}^{+}$イオンの並進運動によりもたらされる イオン伝導が, $\mathrm{BH}_{4}^{-}$の分子性陰イオンの運動性と無関倸で はないことを示していると考えられる。良く知られた高プロ トン伝導体である $\mathrm{CsHSO}_{4}, \mathrm{CsH}_{2} \mathrm{PO}_{4}$ などのオキソ酸塩では, $\mathrm{PO}_{4}{ }^{3-}$ あるいは $\mathrm{SO}_{4}{ }^{2-}$ イオン間の水素結合ネットワークが, $\mathrm{SO}_{4}^{2-}$ あるいは $\mathrm{PO}_{4}{ }^{3-}$ イオンの回転運動に伴う，ネットワー クの組み換えによって再配置し，それによる水素イオン（プ ロトン）の高速移動が起こるというメカニズムが提案されて いる ${ }^{18)}$. その際, 分子性除イオンの回転運動速度とプロト ンの並進拡散との間には密接な関倸があり, 本研究でみられ る $\mathrm{BH}_{4}{ }^{-}$アニオンの分子内回転と $\mathrm{Li}$ の並進運動性との類似性 が見てとれる。したがって，この特異的な $\mathrm{LiBH}_{4}$ でみられ る超イオン伝導特性と分子性イオンの運動性との関係は, 今 後のイオン伝導体の材料設計のために非常に興味樑い示唆を 与えていると考えられる.

\section{4 その他の水素化物への展開}

$\mathrm{LiBH}_{4}$ での高イオン伝導相の発見から, 松尾, 大口らは $\mathrm{BH}_{4}^{-}, \mathrm{AlH}_{4}^{-}, \mathrm{AlH}_{6}{ }^{3-}$ 及びアミド，イミド基，ハロゲン化物 との複合体へと展開し, リチウムイオン伝導を示す物質群が $\mathrm{LiBH}_{4}$ 以外にも多く存在することをごく最近明らかにした。

Fig. 9 に, ミリングによって得られた $\mathrm{Li}\left(\mathrm{NH}_{2}\right)$ - LiI 系の伝導 度と, 放射光 Rietveld 解析から決定した新規化合物である $\mathrm{Li}_{3}\left(\mathrm{NH}_{2}\right)_{2} \mathrm{I}$ の化学量論組成化合物の結晶構造を示す ${ }^{19)}$. 伝 導度は $\mathrm{LiI}=0.25$ の組成で最大值を示し，この層状化合物が 高いイオン伝導度を持つと考えられる.イオン輸率はほほ 1 であることが確かめられ， $\mathrm{Li}^{+}$イオン伝導である.

一方, 松尾らは $\mathrm{Li}_{2}\left(\mathrm{BH}_{4}\right)\left(\mathrm{NH}_{2}\right)$ および $\mathrm{Li}_{4}\left(\mathrm{BH}_{4}\right)\left(\mathrm{NH}_{2}\right)_{3}$ に扔いても， $\mathrm{Li}^{+}$イオン伝導性が発現することを最近明らか にした ${ }^{20)}$. Fig. 10 に示す比較的複雑なその結晶構造は $\mathrm{BH}_{4}^{-}$ 陰イオンと $\mathrm{NH}_{2}{ }^{-}$除イオンを両方含む複塩であり, 複数の $\mathrm{Li}^{+}$ サイトが存在する ${ }^{21)}$ 。このような複雑な配位多面体を持っ た水素化物で，そのイオン伝導特性が明らかになることによ り，材料系の幅が大きく広がりつつある.

さらに，大口らは $\mathrm{LiAlH}_{4}, \mathrm{Li}_{3} \mathrm{AlH}_{6}$ などの錯体水素化物に
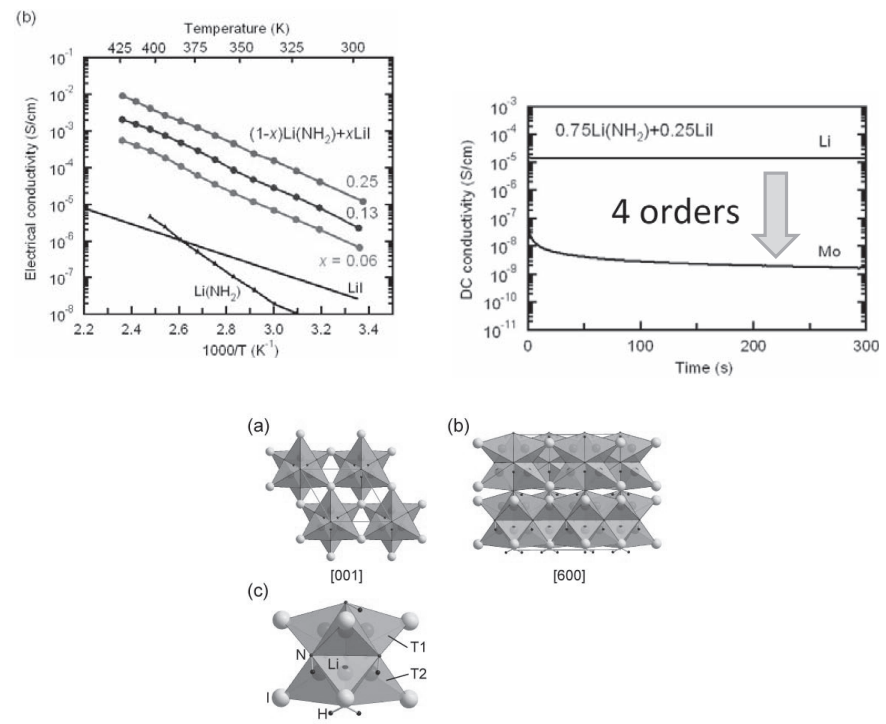

[600]

Fig. 9 (上左) $(1-x) \operatorname{Li}\left(\mathrm{NH}_{2}\right)+x \operatorname{LiI}(x=0.06, \quad 0.13, \quad 0.25)$ の加熱 過程における $\mathrm{Li}$ イオン伝導度のアレニウスプロット（上右） $\mathrm{Li}_{3}$ $\left(\mathrm{NH}_{2}\right)_{2} \mathrm{I}$ の電極の違いによる直流伝導度の変化 (下) $\mathrm{Li}_{3}\left(\mathrm{NH}_{2}\right)_{2} \mathrm{I}$ の放射光 Rietveld 解析から決定した結晶構造. (a) [001]，（b） [600] 方向, (c) 6つの四面体から構成されるクラスター ${ }^{19)}$.

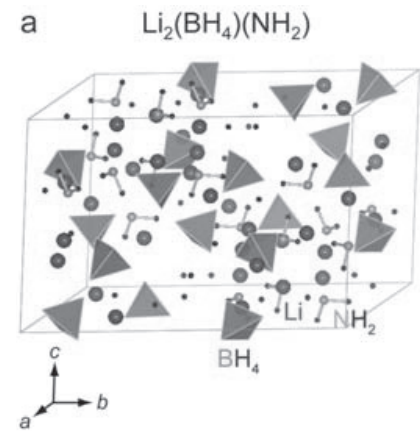

b $\quad \mathrm{Li}_{4}\left(\mathrm{BH}_{4}\right)\left(\mathrm{NH}_{2}\right)_{3}$
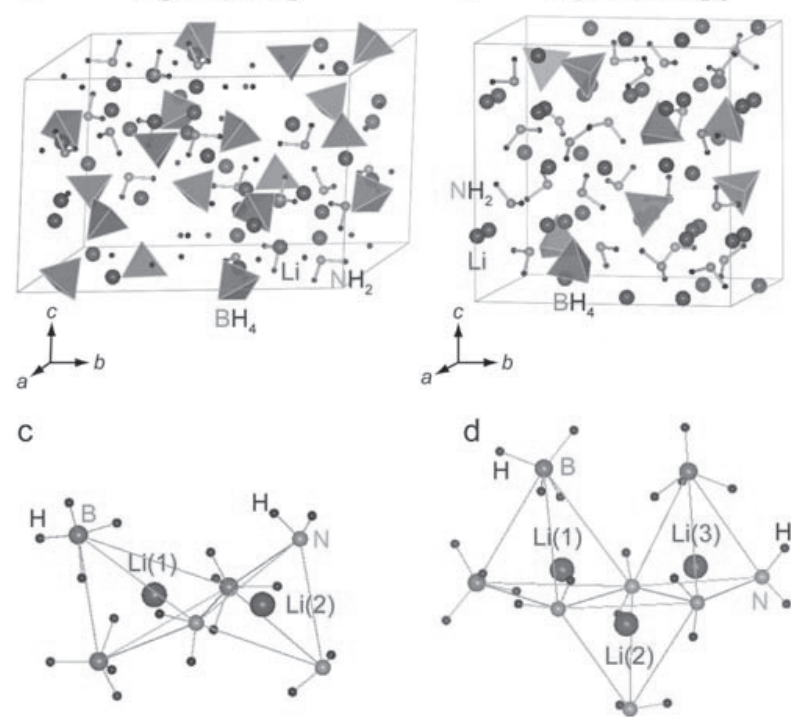

Fig. 10 (a) $\mathrm{Li}_{2}\left(\mathrm{BH}_{4}\right)\left(\mathrm{NH}_{2}\right)$ および (b) $\mathrm{Li}_{4}\left(\mathrm{BH}_{4}\right)\left(\mathrm{NH}_{2}\right)_{3}$ の結晶 構造 ${ }^{20,21)}$. (c), (d) $\mathrm{Li}$ 占有サイトの構造. $\mathrm{Li}_{2}\left(\mathrm{BH}_{4}\right)\left(\mathrm{NH}_{2}\right)$ では $3\left(\mathrm{BH}_{4}\right)^{-}+1\left(\mathrm{NH}_{2}\right)^{-}$及び $1\left(\mathrm{BH}_{4}\right)^{-}+3\left(\mathrm{NH}_{2}\right)^{-}$の四面体位置を, $\mathrm{Li}_{4}$ $\left(\mathrm{BH}_{4}\right)\left(\mathrm{NH}_{2}\right)_{3}$ では $2\left(\mathrm{BH}_{4}\right)^{-}+2\left(\mathrm{NH}_{2}\right)^{-}, 4\left(\mathrm{NH}_{2}\right)^{-}, 1\left(\mathrm{BH}_{4}\right)^{-}+3$ $\left(\mathrm{NH}_{2}\right)^{-}$の四面体を占める.

おいても, リチウムイオン伝導が発現することを明らかにし た. Fig. 11 に $\mathrm{LiAlH}_{4}, \mathrm{Li}_{3} \mathrm{AlH}_{6}$ およびそれらのハロゲン混 合体のイオン伝導度を示す ${ }^{22)}$. 特に興味深い点は, ハロゲ ン化合物の複合化により, 若干の格子の収縮と伝導度の向上 が見られた点であり， $\mathrm{AlH}_{4}{ }^{-}$陰イオンと比較して $\mathrm{AlH}_{6}{ }^{3-}$ 陰 イオンへのドープによりより高い伝導度が実現していること である.イオン半径は, $\mathrm{AlH}_{6}{ }^{3-}(0.256 \mathrm{~nm})>\mathrm{I}^{-}(0.211 \mathrm{~nm})>$ $\mathrm{Cl}^{-}(0.168 \mathrm{~nm})$ であることと, 電荷の異なる陰イオン置換 

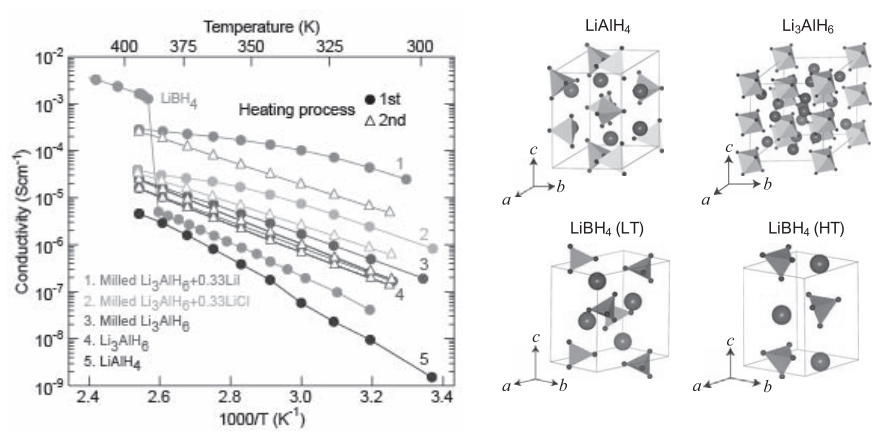

Fig. 11 (左) $393 \mathrm{~K}$ における $\mathrm{LiAlH}_{4}, \mathrm{Li}_{3} \mathrm{AlH}_{6}$ およびそれらのハ ロゲン化物ドープ複合体の加熱過程におけるイオン伝導度 ${ }^{22)}$.

(1) $\mathrm{Li}_{3} \mathrm{AlH}_{6}+0.33 \mathrm{LiI}$ (ミリング), (2) $\mathrm{Li}_{3} \mathrm{AlH}_{6}+0.33 \mathrm{LiCl}$ (ミリ ング), (3) $\mathrm{Li}_{3} \mathrm{AlH}_{6}$ (ミリング), (4) $\mathrm{Li}_{3} \mathrm{AlH}_{6}$, （5） $\mathrm{LiAlH}_{4}$. 比 較のために $\mathrm{LiBH}_{4}$ の結果もプロットしている。（右） $\mathrm{LiAlH}_{4}$, $\mathrm{Li}_{3} \mathrm{AlH}_{6}$ および $\mathrm{LiBH}_{4}$ の高温相, 低温相の結晶構造.

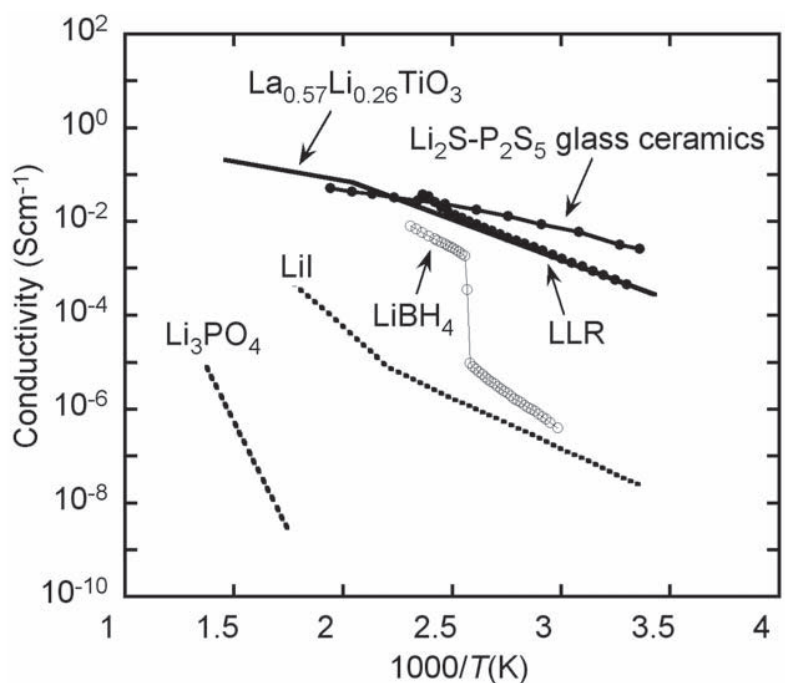

Fig. $12 \mathrm{LiPO}_{3}, \quad \mathrm{LiI}, \quad \mathrm{LiBH}_{4}, \quad \operatorname{LLT}\left(\mathrm{La}_{0.57} \mathrm{Li}_{0.26} \mathrm{TiO}_{3}\right), \quad \mathrm{Li}_{2} \mathrm{~S}-\mathrm{P}_{2} \mathrm{~S}_{5}$ ガ ラスセラミックスおよび, 陽イオン置換 $\operatorname{LiI}-\mathrm{Li}\left(\mathrm{BH}_{4}\right)$ 複合体 (LLR) の伝導度 ${ }^{23)}$.

$\left(\mathrm{AlH}_{6}{ }^{3-} \rightarrow \mathrm{Cl}^{-}, \mathrm{I}^{-}\right)$によって $\mathrm{Li}^{+}$イオン欠陥がより多く生成 する可能性と伝導度向上の傾向が矛盾しないことから，この 種の錯体陰イオンへの材料化学的アプローチとして大変興味 深い.

最近, 熊谷らは, $\mathrm{Li}^{+}$イオンの一部を陽イオンで置換した 複合体 $(\mathrm{LLR})$ で $3 \mathrm{LiBH}_{4} \cdot \mathrm{LiI}$ と比較して伝導度が向上する ことを示した ${ }^{23)}$. NMR，XRDの結果から，この試料は $\mathrm{LiBH}_{4}$ に LiI が固溶した相と $150{ }^{\circ} \mathrm{C}$ 融点を持つ相の混相で ある. Fig. 12 に示すように，この組成ではこれまで知られ ている酸化物系で最高の伝導度を持つ LLT $\left(\mathrm{La}_{0.57} \mathrm{Li}_{0.26} \mathrm{TiO}_{3}\right)$ と同程度の伝導度であり, 実電池として対象となる伝導度域 に達していると考えている。

\section{5 固体電池への応用展開}

$\mathrm{LiBH}_{4}$ は強還元性の化合物であり, その反応は電気化学界 面での卑な反応の促進を期待させる．実際に電気化学的反応 性を確認すると, $\mathrm{LiBH}_{4}$ と $\mathrm{Li}$ 金属の界面は非常に良好であ る.このことは, リチウム電池材料として, 特に負極特性に
優れた材料であることが期待できる. $\mathrm{LiBH}_{4}$ を電解質として 用いた $\mathrm{Li}\left|\mathrm{LiBH}_{4}\right| \mathrm{LiCoO}_{2}$ 全固体電池は, $120^{\circ} \mathrm{C}$ で開回路電 位として熱力学に期待される電位を示すことが確かめられて いる ${ }^{24)}$. また, $\mathrm{Li} / \mathrm{LiBH}_{4}$ 複合体を負極に用いることで電気 化学的反応性が向上することが確認されている ${ }^{25)}$. SEM に よる電極と電解質の界面の観察の結果から, 複合化によって 界面での充放電に伴う体積変化が緩和されると考えている. 現在, 筆者らは水素化物を電解質とした固体電池のための材 料開発に JST 先端的低炭素化技術開発事業（ALCA）によ って取り組んでいる. 正極薄膜に保護層を導入することで充 放電可能な全固体電池を作製でき, 出力向上が期待できると 考えている.

\section{6 おわりに}

水素化物において, その水素吸蔵特性は, 熱力学的因子と ともに速度論的因子が非常に重要である. そのため, イオン 移動に伴う水素吸放出反応が水素吸放出特性改善のため広範 な研究対象になっており, 特に $\mathrm{LiBH}_{4}$ などの錯体系水素化 物への $\mathrm{TiCl}_{3}, \mathrm{ZrCl}_{4}$ などの遷移金属ハロゲン化物のドープ による水素放出反応の活性化エネルギーの低下と水素放出温 度の低下が報告されている。これは, 触媒的な水素放出分解 反応の促進とともに, 本稿で述べた, イオン運動性と密接に 関連している可能性があり，この分野におけるイオン伝導機 能性と水素吸放出機能の相関を系統的に調査することにより, 水素吸放出材料の機能向上, 並びにイオン伝導材料の新機能 開拓の両面から極めて重要な課題である.さらなる高イオン 伝導性材料開拓の可能性がある新しい分野であると考えてい る. 大学院学生諸氏の挑戦に期待したい.

\section{7 謝辞}

本研究は, 東北大学大学院工学研究科高村仁准教授, 金属 材料研究所折茂慎一教授の研究室及びそのメンバーとの共同 研究の成果である。 また, ここで紹介した研究の一部は, 科 学研究費補助金「特定領域研究」439ナノイオニクス, 基盤 研究 (B) 21360314, NEDO 水素貯蔵材料先端基盤研究事業 Hydro ¿ Star「水素貯蔵材料における M-e-H 相互作用の NMR 分光解析」, JST 先端的低炭素化技術開発事業 (ALCA) 「高速充放電を可能とする全固体電池要素材料の研究」の支 援により行われたものである。ここに謝辞を述べる。

* NASICON : Na super ionic conductor の略で, 一連の $\mathrm{Na}^{+}$イオン伝導性酸素酸塩化合物の総称である。代表 的 NASICON は $\mathrm{NaZr}_{2}\left(\mathrm{PO}_{4}\right)_{3}$ と $\mathrm{Na}_{4} \mathrm{Zr}_{2}\left(\mathrm{SiO}_{4}\right)_{3}$ の固溶 体であり, 3 次元的伝導チャンネルを有する.

\section{文 献}

1) E. Masdupuy, Ann. Chim. (Paris), 13, 527 (1957).

2) U. V. Alpen, A. Rabenau, and G. H. Talat, Appl. Phys. Lett., 30, 621 (1977).

3) T. Lapp, S. Skaarup, and A. Hooper, Solid State Ionics, 11, 97 (1983).

4) H. Schulz and K. H. Thiemann, Acta Cryst., A35, 309 (1979).

5) B. A. Boukamp and R. A. Huggins, Phys. Lett., 72A, 464 (1979).

6) K. Ohoyama, Y. Nakamori, S. Orimo, and K. Yamada, J. 
Phys. Soc. Japan, 74, 483 (2005).

7) S. Orimo, Y. Nakamori, J. R. Eliseo, A. Zuttel, and C. M. Jensen, Chem. Rev., 107, 4111 (2007).

8) M. Matsuo, Y. Nakamori, K. Yamada, and S. Orimo, Appl. Phys. Lett., 90, 232907 (2007).

9) M. Matsuo, Y. Nakamori, S. Orimo, H. Maekawa, and H. Takamura, Appl. Phys. Lett., 91, 224103 (2007).

10) H. Maekawa, M. Matsuo, H. Takamura, M. Ando, Y. Noda, T. Karahashi, and S. Orimo, J. Am. Chem. Soc., 131, 894 (2009).

11) A. Abragam, in The Princeples of Nuclear Magnetism, Oxford at the Clarendon Press, p.300 (1961).

12) C. W. F. T. Pistorius, Z. Phys. Chem. Neue Folge, 88, S253 (1974).

13) H. Takamura, Y. Kuronuma, H. Maekawa, M. Matsuo, and S. Orimo, Solid State Ionics, Available online 31 March (2010).

14) J-Ph. Soulié, J. Alloys Compd., 346, 200 (2002).

15) M. Matsuo, H. Takamura, H. Maekawa, H.-W. Li, and S. Orimo, Appl. Phys. Lett., 94, 084103 (2009).

16) H. Oguchi, M. Matsuo, J. S. Hummelshøj, T. Vegge, J. K. Nørskov, T. Sato, Y. Miura, H. Takamura, H. Maekawa, and S. Orimo, Appl. Phys. Lett., 94, 141912 (2009).

17) R. Miyazaki, T. Karahashi, N. Kumatani, Y. Noda, M. Ando, H. Takamura, M. Matsuo, S. Orimo, and H. Maekawa, Solid State Ionics, In Press, Available online 17 June 2010.

18) A. Ishikawa, H. Maekawa, T. Yamamura, Y. Kawakita, K. Shibata, and M. Kawai, Solid State Ionics, 179, 2345 (2008).

19) M. Matsuo, T. Sato, Y. Miura, H. Oguchi, Y. Zhou, H.
Maekawa, H. Takamura, and S. Orimo, Chem. Mater., 22, 2702 (2010).

20) M. Matsuo, A. Remhof, P. Martelli, R. Caputo, M. Ernst, Y. Miura, T. Sato, H. Oguchi, H. Maekawa, H. Takamura, A. Borgschulte, A. Züttel, and S. Orimo, J. Am. Chem. Soc., 131, 16389 (2009).

21) H. Wu, W. Zhou, T. J. Udovic, J. J. Rush, and T. Yildirim, Chem. Mater., 20, 1245 (2008).

22) H. Oguchi, M. Matsuo, T. Sato, H. Takamura, H. Maekawa, H. Kuwano, and S. Orimo, J. Appl. Phys., 107, 096104 (2010).

23) N. Kumatani, K. Kanno, R. Miyazaki, H. Takamura, M. Matsuo, S. Orimo, and H. Maekawa, Collected Abstracts of the 2011 Spring Meeting of The Japan Institute of Metals (2011) [in Japanese].

24) K. Okuhata, R. Miyazaki, H. Maekawa, K. Kami, and G. Suzuki, Collected Abstracts of the 2011 Spring Meeting of The Japan Institute of Metals (2011) [in Japanese].

25) T. Yamazaki, K. Takahashi, K. Hattori, R. Miyazaki, H. Takamura, M. Matsuo, S. Orimo, K. Takada, and H. Maekawa, Collected Abstracts of the 2011 Spring Meeting of The Japan Institute of Metals (2011) [in Japanese].

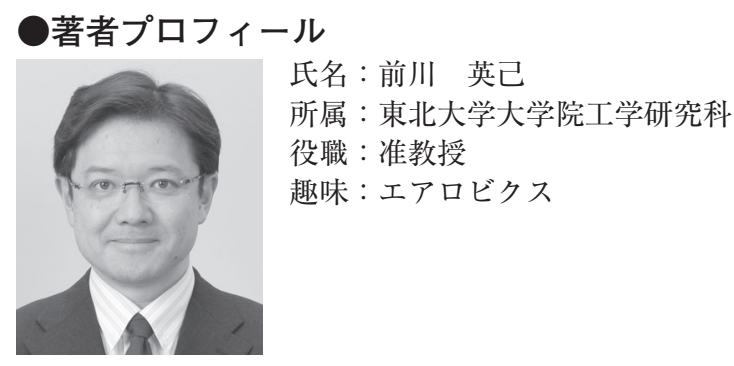

\section{马) 水酸化物イオン伝導性 無機固体材料の創製}

\section{忠永 清治, 辰巨砂昌弘}

\section{1 はじめに}

アルカリ性の水溶液は, 様々な電気化学素子の電解質とし て用いられている. 現在, 様々な電気化学素子の固体化が注 目されている中で, アルカリ性水溶液電解質の固体化に関し ても，その検討が少しずつ始まっている.

アルカリ性水溶液電解質を用いる電気化学素子の代表例と して，アルカリ形燃料電池 (alkaline fuel cells, AFC) を挙 げることができる。この燃料電池においては， $\mathrm{KOH}$ などの アルカリ性水溶液が電解質として用いられる。塩基性の電解 質を用いることによって，安価なニッケルや銀をアノード触 媒に用いることができること, 白金触媒を用いたカソードで の酸素の還元反応が容易に起こること, 多様な燃料が使用可 能であること, といった点で固体高分子形燃料電池 (PEFC) よりも有利な面を有する. しかしながら, $\mathrm{KOH}$ や $\mathrm{NaOH}$ な どのアルカリ金属水酸化物の水溶液を電解質に用いた $\mathrm{AFC}$ では, 燃料ガスや空気中の $\mathrm{CO}_{2}$ と水酸化物イオンの反応に より炭酸イオンが生成し, 電解質中のアルカリ金属イオンと
金属炭酸塩を形成する。このことは電解質の導電率を下げる だけでなく，溶解度が低いことによって電極と電解質の界面 で金属炭酸塩が析出し，電極反応を阻害するといった問題が ある。これらのことから， AFC は宇宙船などの非常に限ら れた用途で用いられてきた ${ }^{1-3)}$.

一方, PEFCの実用化に向けて, Pt 触媒の使用量の低減, あるいは高活性化, また, 非 Pt 系触媒の開発が盛んに行わ れている。このような中で, PEFCには長期間運転における 白金触媒の溶解の問題があり，白金に代わる触媒を開発する 上でも，電解質が酸性であることは大きな障害となっている. さらに，現在，セパレータに主に用いられているグラファイ 卜板はコストが高く, これを低減するために安価な金属の使 用が期待されるが, 酸性の電解質の場合には腐食の問題が生 じる.このようなことから, 塩基性の電解質を用いた燃料電 池の開発に期待が寄せられている.

そこで近年, アルカリ形燃料電池の固体化の方法として, アニオン交換膜を水酸化物イオン伝導体として用いたアルカ 